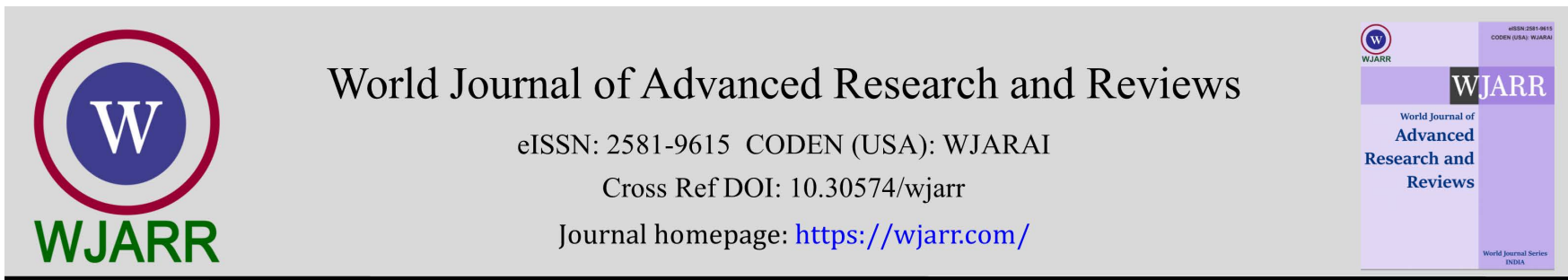

(RESEARCH ARTiClE)

Check for updates

\title{
The effect of shadow conditions on stomatal characters of several plants used in landscape design
}

\author{
Hakan Sevik 1, ${ }^{*}$, Mehmet Cetin ${ }^{2}$, Nurcan Yigit ${ }^{3}$, Burak Aricak ${ }^{3}$, Sevgi Ozturk ${ }^{2}$, Ayse Kalayci Onac ${ }^{4}$ and Inci \\ Sevinc Kravkaz Kuscu ${ }^{3}$ \\ ${ }^{1}$ Faculty of Architecture and Engineering, Department of Environmental Engineering, Kastamonu University, Kastamonu, \\ Turkey. \\ ${ }^{2}$ Faculty of Architecture and Engineering, Department of Landscape Architecture, Kastamonu University, Kastamonu, \\ Turkey. \\ ${ }^{3}$ Faculty of Forestry, Department of Forest Engineering, Kastamonu University, Kastamonu, Turkey. \\ ${ }^{4}$ Faculty of Architecture and Engineering, Department of City and Regional Planning, İzmir Katip Celebi University, İzmir, \\ Turkey.
}

World Journal of Advanced Research and Reviews, 2021, 09(03), 109-115

Publication history: Received on 02 February 2021; revised on 04 March 2021; accepted on 06 March 2021

Article DOI: https://doi.org/10.30574/wjarr.2021.9.3.0086

\begin{abstract}
The present study aims to determine the changes in stomatal characters of several plants depending on the shadow conditions. Within this scope, the leaf samples were collected from Platanus orientalis, Cercis siliquastrum, Eonymus japonica, Cotoneaster franchettii, and Buxus sempervirens species grown in open spaces. Scales images of leaf samples were taken using Scanning Electron Microscope and measurements were performed on these images in order to determine the micro-morphological characteristics such as stoma length $(\mu \mathrm{m})$, stoma width $(\mu \mathrm{m})$, pore opening length $(\mu \mathrm{m})$, and pore opening width $(\mu \mathrm{m})$ in the statistical analyses. The changes of these characteristics depending on the species, individuals, and shadow conditions were determined. The results showed that the differences in stomatal characteristics were statistically significant only between the individuals, whereas the effects of light and individual were statistically non-significant.
\end{abstract}

Keywords: Stoma; Stomatal Characteristics; Light; Micromorphology

\section{Introduction}

Plants fulfill various economic, ecological, and social functions in places, where they are grown [1,2]. However, these plants' ability to fulfill their functions depends on their health and their ability to maintain their proper development. Plants' growth, their morphological, anatomic, and phenological characteristics, and consequently any type of phenotypic characteristic are affected by the mutual interaction between genetic structure $[3,4]$ and environmental conditions [5,6]. One of the most important environmental factors influencing the growth of plants is the light [7]. Although many studies investigated the effects of light on the development and morphological characteristics of plants, there are few studies examining how the stomatal characteristics are affected [8].

Stomas are the structures controlling the intake-output of $\mathrm{CO}_{2}$ and water vapor in leaves and having vital importance for the plant [9]. If the factors affecting the development of stomatal characteristics can be determined, then this information can be used in many fields such as examining the stress status of plants, as well as genetic variation studies. Within the scope of the present study, it was aimed to determine the change of stomatal characteristics depending on

\footnotetext{
* Corresponding author: Hakan sevik

Faculty of Architecture and Engineering, Department of Environmental Engineering, Kastamonu University, Kastamonu, Turkey.. Copyright (c) 2021 Author(s) retain the copyright of this article. This article is published under the terms of the Creative Commons Attribution Liscense 4.0.
} 
the plant species, individual, and shadow conditions. In order to eliminate the effects of other factors, the present study involved only the leaf samples, which were grown in shadowy and sunny conditions and taken from the same plant.

\section{Material and methods}

The present study was carried out using Platanus orientalis, Cercis siliquastrum, Eonymus japonica, Cotoneaster franchettii, and Buxus sempervirens, which are frequently used in landscaping activities in Turkey and Europe. Within the scope of this study, three adult individuals, which fit the purpose of the study and were grown totally in open space (not affected by any structure or object nearby), from each species were determined. Then, 20 leaf samples were collected; 10 leaf samples from the individuals completely grown under light conditions and exposed to no shadow and 10 leaf samples from the individuals completely grown under darkest shadow conditions. The leaf samples were collected since the mid of August.

The collected leaf samples were pressed using the standard pressing method and then dried. Maximum effort was made in order to keep samples clean and free of any mold, fungus, etc. Then, the samples were taken to the laboratory and examined using an electron microscope. In examining the leaf samples, the images were taken from the leaf blade at a point close to the middle. The images obtained were recorded as ".jpeg" files. After these steps, ImageJ software was used in micromorphological measurements. Using this software, the following measurements were made:

STL: Stoma length $(\mu \mathrm{m})$

STW: Stoma width $(\mu \mathrm{m})$

PORL: Pore opening length $(\mu \mathrm{m})$, and

PORW: Pore opening width $(\mu \mathrm{m})$

The data obtained were analyzed in SPSS software using variance analysis and Duncan test and it was aimed to determine the changes in stomatal characteristics depending on the individual, species, and shadow conditions.

\section{Results}

Species-level mean values of the characteristics examined in the present study, F values obtained from the variance analysis, level of importance, and groupings found in the Duncan test are presented in Table 1.

Table 1 Changes in characteristics by the species.

\begin{tabular}{|l|l|l|l|l|}
\hline Species & PORL $(\boldsymbol{\mu m})$ & PORW $(\boldsymbol{\mu m})$ & STL $(\boldsymbol{\mu m})$ & STW $(\boldsymbol{\mu m})$ \\
\hline Platanus orientalis & $17,26 \mathrm{~d}$ & $8,30 \mathrm{c}$ & $33,89 \mathrm{~b}$ & $27,26 \mathrm{~cd}$ \\
\hline Cercis siliquastrum & $14,97 \mathrm{c}$ & $4,94 \mathrm{a}$ & $22,48 \mathrm{a}$ & $12,59 \mathrm{a}$ \\
\hline Eonymus japonica & $11,29 \mathrm{~b}$ & $6,61 \mathrm{~b}$ & $24,30 \mathrm{a}$ & $19,60 \mathrm{~b}$ \\
\hline Cotoneaster franchettii & $5,94 \mathrm{a}$ & $9,87 \mathrm{~d}$ & $24,40 \mathrm{a}$ & $26,41 \mathrm{c}$ \\
\hline Buxus sempervirens & $5,96 \mathrm{a}$ & $10,75 \mathrm{~d}$ & $24,32 \mathrm{a}$ & $28,87 \mathrm{~d}$ \\
\hline F Value & 52,716 & 25,183 & 32,551 & 133,583 \\
\hline Sig. & 0,000 & 0,000 & 0,000 & 0,000 \\
\hline
\end{tabular}

Examining the table values, it can be seen that all the characteristics significantly differed by the species at the confidence level of $99.9 \%$. It was interesting that the plane stomas were in the final homogeneous group in all the stomatal characteristics.

Species-level mean values of leaf characteristics of individuals grown under light, as well as F values obtained from variance analysis, level of significance, and groups forming after Duncan test, are presented in Table 2. 
Table 2 Species-based changes in characteristics of individuals grown under light conditions.

\begin{tabular}{|l|l|l|l|l|}
\hline Species & PORL $(\boldsymbol{\mu m})$ & PORW $(\boldsymbol{\mu m})$ & STL $(\boldsymbol{\mu m})$ & STW $(\boldsymbol{\mu m})$ \\
\hline Platanus orientalis & $17,88 \mathrm{c}$ & $8,89 \mathrm{~b}$ & $34,25 \mathrm{c}$ & $27,41 \mathrm{c}$ \\
\hline Cercis siliquastrum & $15,28 \mathrm{c}$ & $4,52 \mathrm{a}$ & $22,33 \mathrm{a}$ & $12,37 \mathrm{a}$ \\
\hline Eonymus japonica & $11,10 \mathrm{~b}$ & $6,00 \mathrm{a}$ & $22,50 \mathrm{a}$ & $18,85 \mathrm{~b}$ \\
\hline Cotoneaster franchettii & $7,68 \mathrm{a}$ & $10,63 \mathrm{bc}$ & $26,34 \mathrm{~b}$ & $27,74 \mathrm{c}$ \\
\hline Buxus sempervirens & $5,70 \mathrm{a}$ & $11,54 \mathrm{c}$ & $24,83 \mathrm{ab}$ & $30,56 \mathrm{~d}$ \\
\hline F Value & 26,681 & 22,257 & 20,854 & 110,233 \\
\hline Sig. & 0,000 & 0,000 & 0,000 & 0,000 \\
\hline
\end{tabular}

Given the values presented in Table 2, it can be seen for the individuals, which were not grown under shadow conditions, that all the characteristics significantly differed at the species level at the confidence level of 99.9\%. The result of Duncan test suggested that Cercis siliquastrum was in the first homogeneous group in all the characteristics except for PORL, whereas the highest values were observed in Platanus orientalis for PORL and STL and in Buxus sempervirens for PORW and STW.

For the individuals grown under shadow conditions, the mean values of leaf characteristics of individuals grown under light, as well as F values obtained from variance analysis, level of significance, and groups forming after Duncan test, are presented in Table 3.

Table 3 Species-based change in the characteristics of individuals grown under shadow conditions.

\begin{tabular}{|l|l|l|l|l|}
\hline Species & PORL $(\boldsymbol{\mu m})$ & PORW $(\boldsymbol{\mu m})$ & STL $(\boldsymbol{\mu m})$ & STW $(\boldsymbol{\mu m})$ \\
\hline Platanus orientalis & $16,64 \mathrm{c}$ & $7,70 \mathrm{~b}$ & $33,54 \mathrm{c}$ & $27,11 \mathrm{c}$ \\
\hline Cercis siliquastrum & $14,66 \mathrm{c}$ & $5,35 \mathrm{a}$ & $22,63 \mathrm{a}$ & $12,82 \mathrm{a}$ \\
\hline Eonymus japonica & $11,48 \mathrm{~b}$ & $7,22 \mathrm{ab}$ & $26,11 \mathrm{~b}$ & $20,35 \mathrm{~b}$ \\
\hline Cotoneaster franchettii & $4,20 \mathrm{a}$ & $9,10 \mathrm{bc}$ & $22,45 \mathrm{a}$ & $25,09 \mathrm{c}$ \\
\hline Buxus sempervirens & $6,23 \mathrm{a}$ & $9,96 \mathrm{c}$ & $23,82 \mathrm{ab}$ & $27,18 \mathrm{c}$ \\
\hline F Value & 28,853 & 7,245 & 17,869 & 54,183 \\
\hline Sig. & 0,000 & 0,000 & 0,000 & 0,000 \\
\hline
\end{tabular}

As with the individuals grown under light conditions, it was also determined for the individuals grown under shadow conditions that all the leaf characteristics significantly differed between the species at the confidence level of $99.9 \%$. According to the results of Duncan test, Cercis siliquastrum was in the first homogeneous group in all the characteristics except for PORL, while the highest values were observed in Cercis siliquastrum and Platanus orientalis for PORL, in Platanus orientalis for STL, and in Buxus sempervirens for PORW and STW. The changes in the characteristics by the individuals grown under light conditions are presented in Table 4. 
Table 4 Individual-level changes in the characters under the light conditions.

\begin{tabular}{|l|l|l|l|l|}
\hline Replication & PORL $(\boldsymbol{\mu m})$ & PORW $(\boldsymbol{\mu m})$ & STL $(\boldsymbol{\mu m})$ & STW $(\boldsymbol{\mu m})$ \\
\hline 1 & 12,90 & 7,77 & 27,19 & 23,42 \\
\hline 2 & 10,79 & 8,39 & 26,21 & 23,25 \\
\hline 3 & 10,90 & 8,79 & 24,74 & 23,48 \\
\hline F Value & 0,722 & 0,358 & 0,783 & 0,004 \\
\hline Sig. & 0,492 & 0,701 & 0,464 & 0,996 \\
\hline
\end{tabular}

Given the values presented in Table, it can be seen that the individual-based changes in the characteristics under the light conditions were not statistically significant $(p>0.05)$. The individual-based changes in the characteristics of individuals grown under shadow conditions are presented in Table 5.

Table 5 Individual-based changes in the characteristics of individuals grown under shadow conditions.

\begin{tabular}{|l|l|l|l|l|}
\hline Replication & PORL $(\boldsymbol{\mu m})$ & PORW $(\boldsymbol{\mu m})$ & STL $(\boldsymbol{\mu m})$ & STW $(\boldsymbol{\mu m})$ \\
\hline 1 & 11,91 & 7,77 & 26,34 & 23,02 \\
\hline 2 & 9,48 & 7,83 & 24,47 & 22,05 \\
\hline 3 & 10,53 & 8,00 & 26,31 & 22,46 \\
\hline F Value & 0,703 & 0,032 & 0,621 & 0,096 \\
\hline Sig. & 0,501 & 0,968 & 0,542 & 0,909 \\
\hline
\end{tabular}

As seen in Table, it can be stated that the individual-based changes in the characteristics of individuals grown under shadow conditions, as well as those grown under light conditions, were not statistically significant $(\mathrm{p}>0.05)$.

\section{Discussion}

As a result of the present study, it was concluded that the stomatal characteristics significantly different only between the species at the confidence level of $95 \%$ and the effects of the light and individual factors were found to be statistically non-significant ( $p>0.05)$. Thus, it can be stated that the most important factor influencing the stomatal characteristics is the plant species.

The phenotypic characteristics of plants are shaped by the genetic structure and environmental conditions [10-14]. The primary factor determining the change in genetic structure is the species. Thus, previous studies reported that the major factor determining the changes in morphological characteristics [15], anatomic characteristics [16], micromorphological characteristics [17,18] and even elemental contents [19-21] is the plant species.

Within the scope of the present study, the changes of stomatal characteristics depending on the species and shadow conditions were determined. Stomas are structures that are formed as a result of differentiation on the epidermis surface of the leaf and control the transpiration and gas exchange through their opening-closing properties [22,23]. The scanning electron microscope, which was used in taking the stoma images within the scope of the present study, provides a high level of magnification thanks to high-resolution imaging techniques. For this reason, it is possible to obtain morphological, structural, and elemental data from the plants at a high zoom level $[9,24]$. The data obtained can be used in various areas such as determining the stress level of plants, genetic variation studies, and determining the most suitable plant growth conditions [8].

However, for stomatal characteristics to be able to be used in specified areas, it is necessary to determine which factors shape these characteristics. Within the scope of the present study, it was found that the stomatal characteristics significantly varied between the species. Previous studies also reported similar results [24]. Moreover, it was also reported in the literature that stomatal characteristics and especially the stoma intensity are important ecophysiological 
parameters shaped by various factors such as drought [25,26], light [7], and salt stress [27,28]. For this reason, stomatal characteristics might be affected by various environmental variables such as intensity, light, shadow, humidity, CO2, and drought $[29,30]$. Because the stomatal characteristics are shaped by environmental factors and genetic structure as all other phenotypic characteristics [8]. Thus, it can be stated that various environmental factors affecting the formation of phenotypic characteristics such as drought, frost, hormone application, air pollution, soil, etc. would also affect the stomatal characteristics.

Stomatal characters are also affected by the genetic structure and the genetic structure significantly varies between the species. Besides that, it is known that genetic variations may be seen within the same species due to differences in growing conditions and origins [31-33]. Previous studies reported that stomatal characteristics might significantly vary between the individuals, which have been grown in the same environment, from the same species [9].

\section{Conclusion}

Study results suggest that stomatal characteristics significantly varied only at the species level, whereas the effects of light and individuals remained statistically insignificant. Stomas are structures that are very important for plants and they might be affected by various environmental and genetic factors. However, there are few studies examining what these factors are and which level of effect they have. Examining the factors affecting stomatal characteristics, further studies on this subject may enable stomatal characteristics to be used in various areas such as the stress level of plants and the genetic variation studies. Thus, further studies on this subject are recommended.

\section{Compliance with ethical standards}

\section{Acknowledgments}

This project supported by the Kastamonu University Scientific Research Projects (Project number is KUBAP-01/201864). We thanks the Kastamonu University Scientific Research Studies Project Management Coordination.

\section{Disclosure of conflict of interest}

The authors declare no conflict of interest.

\section{References}

[1] Yigit N, Öztürk A, Sevik H. Ecological impact of urban forests (Example of Kastamonu urban forest). International Journal of Engineering Sciences \& Research Technology. 2014; 3(12): 558-562.

[2] Aricak B, Cetin M, Erdem R, Sevik H, Cometen H. The usability of Scotch pine (Pinus sylvestris) as a biomonitor for traffic-originated heavy metal concentrations in Turkey. Polish Journal of Environmental Studies. 2020; 29(2): 1051-1057.

[3] Hrivnák M, Paule L, Krajmerová D, Kulaç Ş, Şevik H, Turna İ, Tvauri I, Gömöry D. Genetic variation in Tertiary relics: The case of eastern-Mediterranean Abies (Pinaceae). Ecology and evolution. 2017; 7(23): 10018-10030.

[4] Imren E, Kurt R, Yucedag C, Bilir N, Ozel HB, Cetin M, Sevik H. Selection of Superior Clones By The MultiDimensional Decision Making Techniques in Scots Pine Seed Orchard, Journal of Forests. 2021; 8(1): 13-22.

[5] Turkyilmaz A, Sevik H, Isinkaralar K, Cetin M. Using Acer platanoides annual rings to monitor the amount of heavy metals accumulated in air. Environ Monit Assess. 2018; 190: 578.

[6] Turkyilmaz A, Sevik H, Cetin M. The use of perennial needles as bio-monitors for recently accumulated heavy metals. Landsc Ecol Eng. 2018; 14(1):115-120.

[7] Sevik H, Cetin M, Kapucu O, Aricak B, Canturk U. Effects of light on morphologic and stomatal characteristics of Turkish Fir needles (Abies nordmanniana subsp. Bornmulleriana Mattf.). Fresenius Environmental Bulletin. 2017; 26(11): 6579-6587.

[8] Yigit N, Cetin M, Sevik H. The Change in Some Leaf Micromorphological Characters of Prunus laurocerasus L. Species by Their Habitat. Turkish Journal of Agriculture-Food Science and Technology. 2018; 6(11): 1517-1521.

[9] Yigit N, Cetin M, Ozturk A, Sevik H, Cetin S. Varitation of Stomatal Characteristics in Broad Leaved Species Based on Habitat. Applied Ecology and Environmental Research. 2019; 17(6): 12859-12868. 
[10] Kravkaz Kuscu IS, Cetin M, Yigit N, Savaci G, Sevik H. Relationship between Enzyme Activity (Urease-Catalase) and Nutrient Element in Soil Use. Polish Journal of Environmental Studies. 2018; 27(5): 2107-2112.

[11] Kravkaz-Kuscu IS, Sariyildiz T, Cetin M, Yigit N, Sevik H, Savaci G. Evaluation of the soil properties and primary forest tree species in Taskopru (Kastamonu) district. Fresenius Environmental Bulletin. 2018; 27(3): 1613-1617.

[12] Sevik H, Cetin M, Ozel HB, Akarsu H, Cetin IZ. Analyzing of usability of tree-rings as biomonitors for monitoring heavy metal accumulation in the atmosphere in urban area: a case study of cedar tree (Cedrus sp.). Environmental Monitoring and Assessment. 2020; 192(1): 23.

[13] Sevik H, Cetin M, Ozel HB, Ozel S, Cetin IZ. Changes in heavy metal accumulation in some edible landscape plants depending on traffic density. Environmental Monitoring and Assessment. 2020; 192(2): 78.

[14] Turkyilmaz A, Sevik H, Isinkaralar K, Cetin M. Use of tree rings as a bioindicator to observe atmospheric heavy metal deposition, Environmental Science and Pollution Research. 2019; 26(5): 5122-5130.

[15] Sevik H, Cetin M, Ozturk A, Yigit N, Karakus O. Changes in micromorphological characters of Platanus orientalis L. leaves in Turkey. Applied Ecology and Environmental Research. 2019; 17(3): 5909-5921.

[16] Yigit N, Sevik H, Cetin M, Gul L. Clonal variation in chemical wood characteristics in Hanönü (Kastamonu) Günlüburun black pine (Pinus nigra Arnold. subsp. Pallasiana (Lamb.) Holmboe) seed orchard. Journal of Sustainable Forestry. 2016; 35(7): 515-526.

[17] Cetin M, Sevik H, Yigit N. Climate type-related changes in the leaf micromorphological characters of certain landscape plants. Environmental monitoring and assessment. 2018; 190(7): 404.

[18] Cetin M, Sevik H, Yigit N, Ozel HB, Aricak B, Varol T. The variable of leaf micromorphogical characters on grown in distinct climate conditions in some landscape plants. Fresenius Environmental Bulletin. 2018; 27(5): 32063211.

[19] Sevik H, Cetin M, Ozel HB, Pinar B. Determining toxic metal concentration changes in landscaping plants based on some factors. Air Quality, Atmosphere \& Health. 2019; 12(8): 983-991.

[20] Sevik H, Cetin M, Ozturk A, Ozel HB, Pinar B. Changes in Pb, Cr and $\mathrm{Cu}$ concentrations in some bioindicators depending on traffic density on the basis of species and organs. Applied Ecology and Environmental Research. 2019; 17 (6): 12843-12857.

[21] Cesur A, Cetin IZ, Aisha AESA, Alrabiti OBM, Aljama AMO, Jawed AA, Cetin M, Sevik, H, Ozel HB. The usability of Cupressus arizonica annual rings in monitoring the changes in heavy metal concentration in air. Environmental Science and Pollution Research, 2021; 1-7.

[22] $\mathrm{Xu} \mathrm{Z,} \mathrm{Zhou} \mathrm{G.} \mathrm{Responses} \mathrm{of} \mathrm{leaf} \mathrm{stomatal} \mathrm{density} \mathrm{to} \mathrm{water} \mathrm{status} \mathrm{and} \mathrm{its} \mathrm{relationship} \mathrm{with} \mathrm{photosynthesis} \mathrm{in} \mathrm{a}$ grass. Journal of experimental botany. 2008; 59(12): 3317-3325.

[23] Liu S, Liu J, Cao J, Bai C, Shi R. Stomatal Distribution and Character Analysis of Leaf Epidermis of Jujube Under Drought Stress. Journal of Anhui Agricultural Science. 2006; 34: 1315-1318.

[24] Sevik H, Cetin M, Ozel HB, Erbek A, Cetin IZ. The effect of climate on leaf micromorphological characteristics in some broad-leaved species. Environment, Development and Sustainability. 2020; 1-13.

[25] Yang HM, Wang GX. Leaf stomatal densities and distribution in Triticum aestivum under drought and CO2 enrichment. Acta Phytoecologica Sinica. 2001; 25: 312-316.

[26] Zhang YP, Wang ZM, Wu YC, Zhang X. Stomatal characteristics of different green organs in wheat under different irrigation regimes. Acta Agronomica Sinica. 2006; 32: 70-75.

[27] Zhao RX, Zhang QB, Wu XY, Wang Y. The effects of drought on epidermal cells and stomatal density of wheat leaves. Inner Mongolia Agricultural Science and Technology. 2001; 6: 6-7.

[28] Romero-Aranda R, Soria T, Cuartero J. Tomato plant-water uptake and plant-water relationships under saline growth conditions. Plant Science. 2001; 160(2): 265-272.

[29] Banon S, Fernandez JA, Franco JA, Torrecillas A, Alarcón JJ, Sánchez-Blanco MJ. Effects of water stress and night temperature preconditioning on water relations and morphological and anatomical changes of Lotus creticus plants. Scientia Horticulturae. 2004; 101(3): 333-342.

[30] Beerling DJ, Kelly CK, Salisbury EJ. Stomatal density of temperature woodland plants over the past seven decades of CO2 increase: a comparison of Salisbury (1927) with contemporary data. Am. J. Bot. 1997; 84: 1572-1583. 
[31] Ozel HB, Varol T, Emir T, Sevik H. Effects of Extraction from Compartment on Soil Enzymes. American Journal of Engineering Research. 2021; 10(2): 115-121.

[32] Aricak B, Cetin M, Erdem R, Sevik H, Cometen H. The change of some heavy metal concentrations in Scotch pine (Pinus sylvestris) depending on traffic density, organelle and washing. Applied Ecology and Environmental Research. 2019; 17(3): 6723-6734.

[33] Sevik H, Guney D, Karakas H, Aktar G. Change to amount of chlorophyll on leaves depend on insolation in some landscape plants. International Journal of Environmental Sciences. 2012; 3(3): 1057-1064. 